\title{
EVOLUTION OF THE Fe-RICH PHASES IN RECYCLED AISi9Cu3 CAST ALLOY DURING SOLUTION TREATMENT
}

Using recycled aluminium cast alloys is profitable in many aspects. Requiring only 5\% of the energy to produce secondary metal as compared to primary metal and generates only $4 \%$ of the $\mathrm{CO}_{2}$ emissions, the recycling of aluminium is therefore beneficial of both environmental and economical point of view. AlSi9Cu 3 is a very frequently employed die-casting alloy. It is used in almost all fields of pressure die casting, especially in the fabrication various motor mounts, pistons, cylinder heads, heat exchangers, air conditioners or gearings. Al-Si-Cu alloys usually contain $\mathrm{Cu}$ and sometimes $\mathrm{Mg}$ as the main alloying elements, together with various impurities such as Fe, Mn or Cr. Presence of the Fe impurity enables the crystallization of brittles needles $\mathrm{Al}_{5} \mathrm{FeSi}$ during solidification, even thought the Fe content is extremely low in a melt, and its presence severely lowers the dynamic fracture toughness of the alloy. Alloying elements such are $\mathrm{Mn}, \mathrm{Cr}, \mathrm{Mo}$ and Be have been used to change the morphology of the $\mathrm{Al}_{5} \mathrm{FeSi}$ needles and $\mathrm{Al}(\mathrm{FeMnMg}) \mathrm{Si}$ skeleton (or "Chinese script") phases.

The present study is a part of larger research project, which was conducted to investigate and to provide a better understanding of the solution annealing on the morphology of Fe-rich intermetallic phases in cast Al-Si-Cu alloys. The Fe-rich changes of typical specimens under different solution heat treatment condition were examined using an optical and scanning electron microscope (SEM). The results show that optimal solution treatment causes increasing of mechanical properties, the change of Si-morphology and reduction iron rich phases.

Keywords: recycled Al-Si cast alloy, Fe-rich intermetallic phases, solution treatment

\section{Introduction}

Al-Si alloys are most universal materials, comprising $85 \%$ to $90 \%$ of the aluminium cast parts produced for the automotive industry (e.g. various motor mounts, engine parts, cylinder heads, pistons, valve retainer, compressor parts, etc.) $[1,2]$.

The application of Al-Si alloy castings in many mechanical components, especially for cars and rail vehicles, has gradually increased in the last years, thanks to the great potential of these materials as replacements for ferrous alloys. Today an increasing amount of the aluminium going into producing new aluminium alloy products is coming from recycled products. The increase in recycled metal becoming available is a positive trend, as secondary metal produced from recycled metal requires only about $2.8 \mathrm{kWh} / \mathrm{kg}$ of metal produced while primary aluminium production requires about $45 \mathrm{kWh} / \mathrm{kg}$ of metal produced. It is to the aluminium industry's advantage to maximize the amount of recycled metal, for both the energy-savings and the reduction of dependence upon overseas sources. Increasing the use of recycled metal is also quite important from the ecological standpoint, since producing aluminium by recycling creates only about $4 \%$ as much $\mathrm{CO}_{2}$ as by primary production [3].

But it is recognized that these recycled Al-Si alloys are not likely to be suitable for fracture-critical components, where higher levels of $\mathrm{Fe}$ and $\mathrm{Si}$ have been shown to degrade fracture resistance. However the likelihood exists that they may perform quite satisfactorily in applications such as those listed where service life is determined by other factors [4].

The quality of recycled Al-Si casting alloys is considered to be a key factor in selecting an alloy casting for a particular engineering application. The microstructure of Al-Si-Cu cast alloy is composed of a certain amount of $\mathrm{Fe}, \mathrm{Mn}$ and $\mathrm{Mg}$ that are present either accidentally, or they are added deliberately to provide special material properties. These elements partly go into solid solution in the matrix and partly form intermetallic particles during solidification. The size, volume and morphology of intermetallic phases are functions of chemistry, solidification conditions and heat treatment $[1,2,5]$. Fe is a common impurity in aluminium alloys that leads to the formation of complex Fe-rich intermetallic phases, and how these phases can adversely affect mechanical properties, especially ductility, and also lead to the formation of excessive shrinkage porosity defects in castings [6]. It is clear that the morphology of Fe-rich intermetallic phases influences harmfully also fatigue properties [7]. Much harmful effect proves the cast defects as porosity and microshrinkages because these defects have larger size than intermetallic phases.

The present study is a part of larger research project, which was conducted to investigate and to provide a better understand-

\footnotetext{
* Eva Tillova, Maria Chalupova, Lenka Hurtalova

Department of Material Engineering, Faculty of Mechanical Engineering, University of Zilina, Slovakia, E-mail: eva.tillova@fstroj.uniza.sk
} 
ing of the influence of $\mathrm{Fe}$ on the structure and mechanical properties in recycled (secondary) AlSi9Cu3 cast alloy.

\section{Experimental part}

Recycled (secondary) AlSi9Cu3 cast alloy with chemical composition given in table 1 was used as an experimental material. The melt was not modified or refined. Experimental cast samples were given a heat treatment - solution treatment for $2,4,8,16$ or 32 hours at three temperatures $\left(505,515\right.$ and $\left.525^{\circ} \mathrm{C}\right)$; water quenching at $40{ }^{\circ} \mathrm{C}$ and natural aging for 24 hours at room temperature. After heat treatment the samples were subjected to a mechanical test. Hardness measurement was preformed by a Brinell hardness tester with a load of $62.5 \mathrm{Kp}, 2.5 \mathrm{~mm}$ diameter ball and a dwell time of $15 \mathrm{~s}$. The Brinell hardness value at each state was obtained by an average of at least six measurements.

Chemical composition of the alloy (wt. \%)

Table 1

\begin{tabular}{|c|c|c|c|c|c|c|c|c|c|}
\hline $\mathrm{Si}$ & $\mathrm{Cu}$ & $\mathrm{Mn}$ & $\mathrm{Fe}$ & $\mathrm{Mg}$ & $\mathrm{Ni}$ & $\mathrm{Pb}$ & $\mathrm{Zn}$ & $\mathrm{Ti}$ & $\mathrm{Al}$ \\
\hline 10.7 & 2.4 & 0.22 & $<0.8$ & 0.47 & 0.08 & 0.11 & 1.1 & 0.03 & rest \\
\hline
\end{tabular}

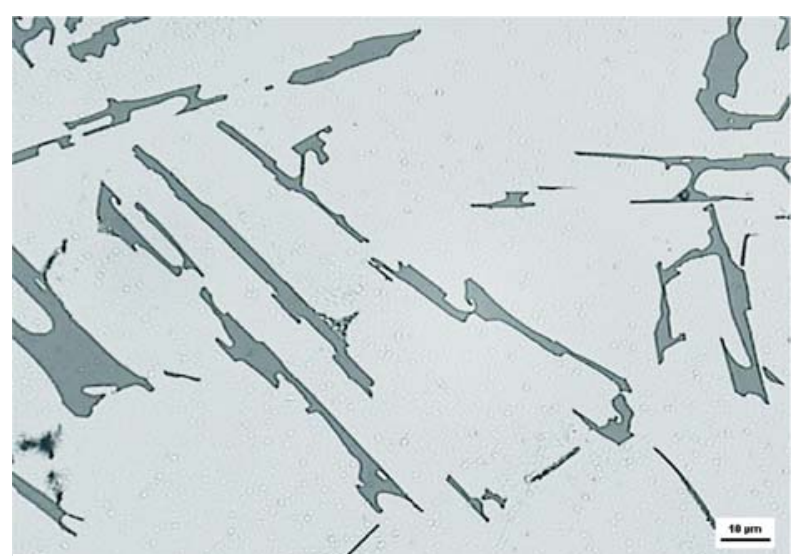

a) untreated state

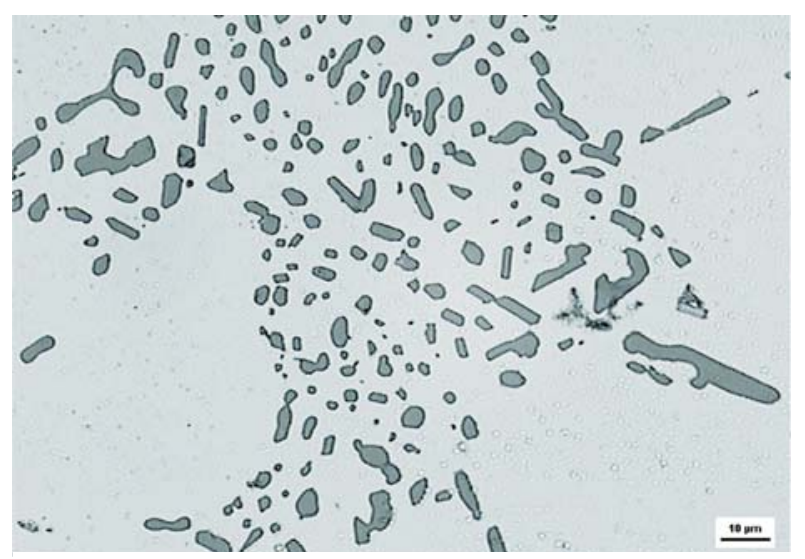

c) $515^{\circ} \mathrm{C}, 4$ hours
Metallographic samples were cut from selected tensile specimens (after testing) and hot mounted for metallographic preparation. The microstructures were studied using an optical microscope Neophot 32. Samples were prepared by standards metallographic procedures (wet ground on SiC papers, DP polished with $3 \mu \mathrm{m}$ diamond pastes followed by Struers Op-S and etched by Dix-Keller, $\mathrm{HNO}_{3}, \mathrm{H}_{2} \mathrm{SO}_{4}$ or MA). To determine the chemical composition of the intermetallic phases a scanning electron microscope (SEM) TESCAN VEGA LMU with EDX analyser BRUKER QUANTAX was employed.

\section{Results and discussion}

The structure of hypoeutectic AlSi9Cu3 cast alloy consists of dendrites $\alpha$-phase (light grey), eutectic (dark grey) and intermetallic $\mathrm{Fe}$ - and $\mathrm{Cu}$-rich phases. The formation of these phases should correspond to successive reaction during solidification Table 2 $[1,4,8]$.

The effect of solution treatment on morphology of eutectic $\mathrm{Si}$ is demonstrated in Fig. 1. The changes in morphology of eutectic

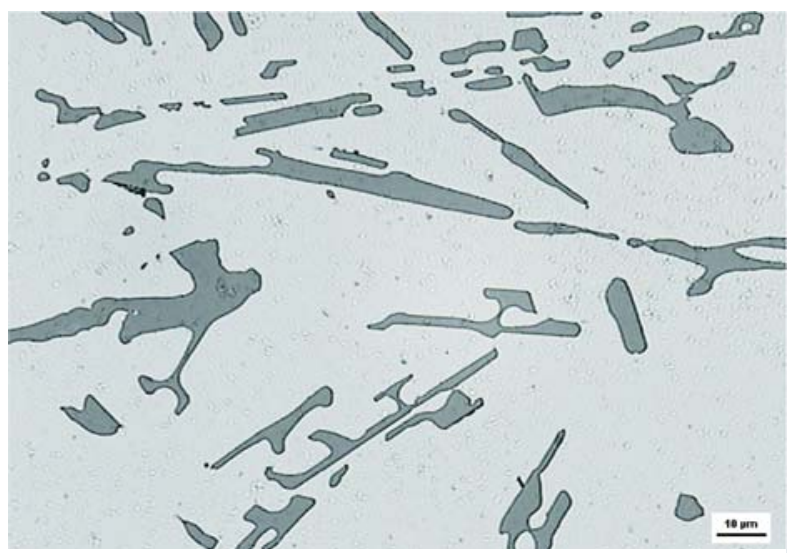

b) $505^{\circ} \mathrm{C}, 4$ hours

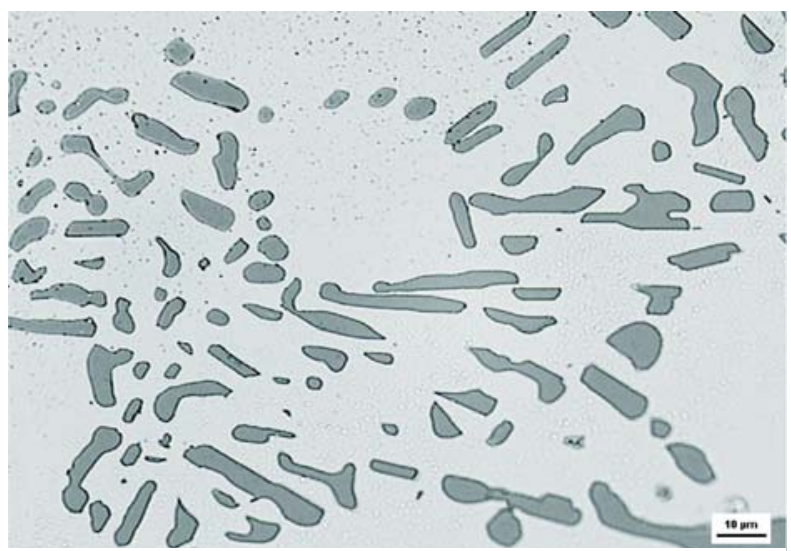

d) $525^{\circ} \mathrm{C}, 4$ hours

Fig. 1 Effect of solution treatment on morphology of eutectic Si, etch. Dix-Keller 
Reactions occurring during solidification of Al-Si-Cu alloy Table 2

\begin{tabular}{|l|c|}
\hline & Temperature, ${ }^{\circ} \mathrm{C}$ \\
\hline$\alpha$ - dendritic network & 609 \\
\hline Liq. $\rightarrow \alpha$ - phase $+\mathrm{Al}_{15}(\mathrm{FeMn})_{3} \mathrm{Si}_{2}+\mathrm{Al}_{5} \mathrm{FeSi}$ & 590 \\
\hline Liq. $\rightarrow \alpha$ - phase $+\mathrm{Si}+\mathrm{Al}_{5} \mathrm{FeSi}$ & 575 \\
\hline Liq. $\rightarrow \alpha$ - phase $+\mathrm{Si}+\mathrm{Mg}_{2} \mathrm{Si}+\mathrm{Al}_{8} \mathrm{Mg}_{3} \mathrm{FeSi}_{2}$ & 554 \\
\hline Liq. $\rightarrow \alpha-$ phase $+\mathrm{Al}_{2} \mathrm{Cu}+\mathrm{Al}_{5} \mathrm{FeSi}+\mathrm{Si}_{1}$ & 525 \\
\hline Liq. $\rightarrow \alpha$ - phase $+\mathrm{Al}_{2} \mathrm{Cu}+\mathrm{Si}+\mathrm{Al}_{5} \mathrm{Mg}_{8} \mathrm{Si}_{6} \mathrm{Cu}_{2}$ & 507 \\
\hline
\end{tabular}

Si observed after heat treatments are documented for holding time of 4 hours. Eutectic Si without heat treatment (untreated state) occurs in platelets form (Fig. 1a). After solution treatment by temperature of $505{ }^{\circ} \mathrm{C}$ we noted that the platelets were fragmentized into smaller platelets with spherical edges (Fig. 1b). The spheroidized process dominated at $515{ }^{\circ} \mathrm{C}$. The smaller Si particles were spheroidized to rounded shape, see Fig. 1c. By solution treatment at $525{ }^{\circ} \mathrm{C}$ the spheroidized particles gradually grew larger (coarsening) (Fig. 1d)

For die casting, $\mathrm{Fe}$ is added to increase hot tear resistance and to reduce die sticking. In Al-Si-Cu type alloys, however, Fe showed to have the most detrimental effect on ductility of all of the common impurities. Iron impurities can either come from the original bauxite ore or be acquired during subsequent melting, remelting and casting, e.g. by contamination from the melting pot etc. Significant levels of $\mathrm{Fe}$ (e.g. $>0.5 \%$ ) can change the solidification characteristics of Al-Si alloys by forming pre- and post-eutectic $\mathrm{Al}_{5} \mathrm{FeSi}$ (know as beta- or $\beta$ - phase $[4,9,10]$ ).

$\mathrm{Al}_{5} \mathrm{FeSi}$ phases precipitate in the interdendritic and intergranular regions as platelets (appearing as needles in the metallographic microscope - Fig. 2a). Long and brittle $\mathrm{Al}_{5} \mathrm{FeSi}$ platelets (more than $500 \propto \mathrm{m})$ can adversely affect mechanical properties, especially ductility, and also lead to the formation of excessive shrinkage porosity defects in castings. It was also shown that the $\mathrm{Al}_{5} \mathrm{FeSi}$ needles can act as nucleation sites for $\mathrm{Cu}$-rich phases (Fig. 2b) [11].

The deleterious effect of $\mathrm{Al}_{5} \mathrm{FeSi}$ can be reduced by increasing the cooling rate, superheating the molten metal, or by the addition of a suitable "neutralizer" like $\mathrm{Mn}, \mathrm{Co}, \mathrm{Cr}, \mathrm{Ni}, \mathrm{V}, \mathrm{Mo}$ and $\mathrm{Be}$. Mn was the most common addition. $\mathrm{Mn}$ excess may reduce $\mathrm{Al}_{5} \mathrm{FeSi}$ phase and promote formation of Fe-rich phases $\mathrm{Al}_{15}(\mathrm{FeMn})_{3} \mathrm{Si}_{2}$ (known as alpha- or $\alpha$-phase [4, 10-13]) in a "skeleton-like" form or in "Chinese script" form - Fig. 3a. This compact morphology "Chinese script" (skeleton - like) does not initiate cracks in the cast material to the same extent as $\mathrm{Al}_{5} \mathrm{FeSi}$ does. If $\mathrm{Mg}$ is also present with $\mathrm{Si}$, an alternative called pi- or $\pi$-phase can form, $\mathrm{Al}_{5} \mathrm{Si}_{6} \mathrm{Mg}_{8} \mathrm{Fe}_{2} . \mathrm{Al}_{5} \mathrm{Si}_{6} \mathrm{Mg}_{8} \mathrm{Fe}_{2}$ has a script-like morphology [4, $12]$.

Fe-rich phases $\left(\mathrm{Al}_{5} \mathrm{FeSi}\right.$ or $\left.\mathrm{Al}_{15}(\mathrm{FeMn})_{3} \mathrm{Si}_{2}\right)$ are completely brittle [1], since their particles break during polishing in slurry of alumina (Fig. 3b). It suggests that the intermetallic phases may act as stress raisers and crack initiation sites that reduce the strength and ductility of the recycled Al-Si-Cu alloys due to the lack of active slip systems in the intermetallic compounds.

Alloying with $\mathrm{Mn}$ and $\mathrm{Cr}$, caution has to be taken in order to avoid the formation of hard complex intermetallic multi-component sludge, $\mathrm{Al}_{15}(\mathrm{FeMnCr})_{3} \mathrm{Si}_{2}$ - phase (Fig. 3c). These intermetallic compounds are hard and can adversely affect the overall properties of the casting. The formation of sludge phases [12] is a temperature dependent process in a combination with the concentrations of iron, manganese and chromium independent of the silicon content.

In recycled $\mathrm{AlSi} 9 \mathrm{Cu} 3$ cast alloy that contains less than $0.8 \%$ of $\mathrm{Fe}$ and $0.22 \% \mathrm{Mn}$ very short and little $\mathrm{A}_{15} \mathrm{FeSi}$ needles were present. Fe-phases precipitate first of all as skeleton-like $\mathrm{Al}_{15}(\mathrm{FeMn})_{3} \mathrm{Si}_{2}$ phase.

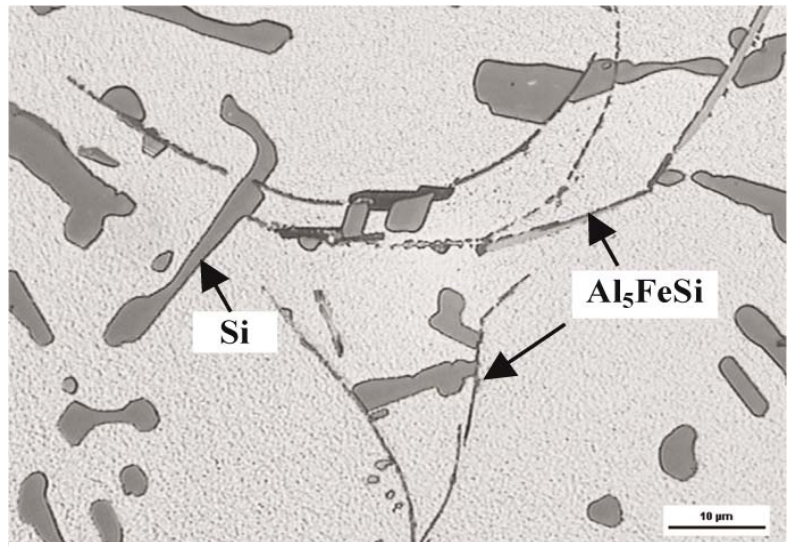

a) $\mathrm{Al}_{5} \mathrm{FeSi}$ needles

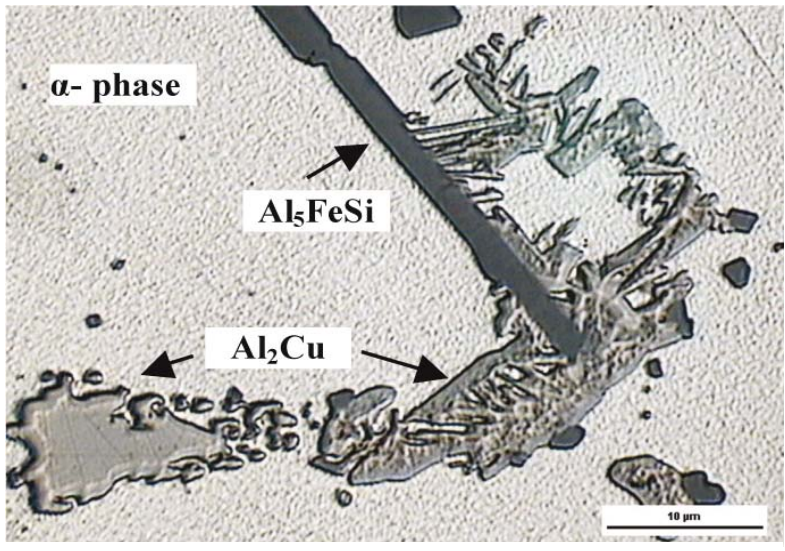

b) $\mathrm{Al}_{5} \mathrm{FeSi}$ needles as nucleation sites for $\mathrm{Cu}$-rich phases

Fig. 2 Morphology of Fe-rich needles in recycled AlSi9Cu3 cast alloy, etch. Dix-Keller 


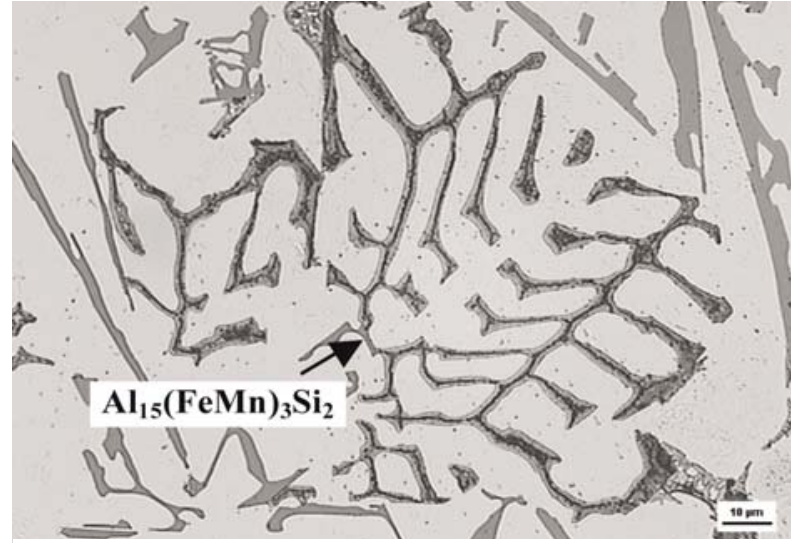

a) $\mathrm{Al}_{15}(\mathrm{FeMn})_{3} \mathrm{Si}_{2}$

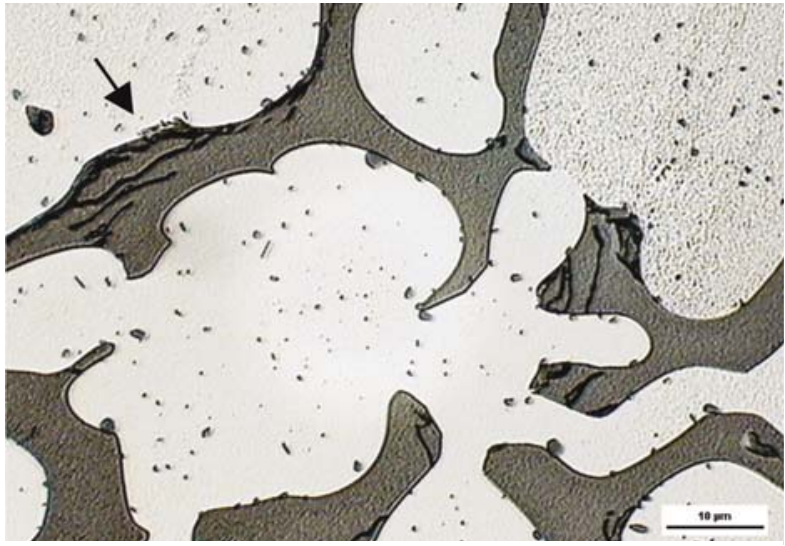

b) detail of brittle $\mathrm{Al}_{15}(\mathrm{FeMn})_{3} \mathrm{Si}_{2}$

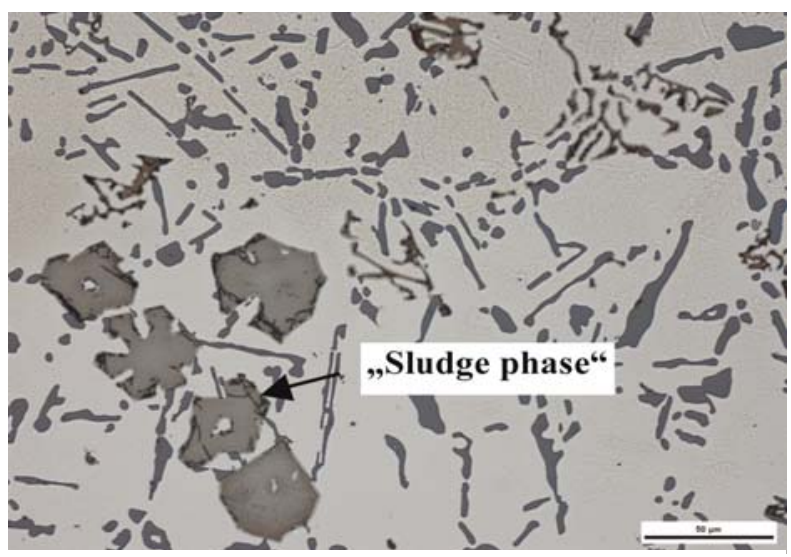

c) typical microstructure of "sludge"

(a coarse form of the $\mathrm{Al}_{15}(\mathrm{FeMn})_{3} \mathrm{Si}_{2}$ phase)

Fig. 3 Morphology of skeleton-like Fe-rich phases in recycled AlSi9Cu3 cast alloy, etch. Dix-Keller

\subsection{The effect of solution treatment on mechanical properties}

Mechanical properties of a cast component are determined largely by the shape and distribution of Si particles in the matrix. Optimum tensile, impact and fatigue properties are obtained with small, spherical and evenly distributed particles.

Heat treatment used to obtain the optimal combination of strength and ductility in casting involves: a) solutionizing to thermally prepare the material; b) quenching to retain the maximum concentration of hardening constituent $\left(\mathrm{Al}_{2} \mathrm{Cu}\right)$ in solid solution and c) a combination of artificial and over-ageing to obtain the desired mechanical properties in the casting [5]. Solution treatment performs three roles: homogenization of as-cast structure; dissolution of certain intermetallic phases such as $\mathrm{Al}_{2} \mathrm{Cu}$; changes the morphology of eutectic Si phase by fragmentation, spheroidization and coarsening, thereby improving mechanical properties, particularly ductility. Most of the recommended heat treatment of alloys that contain cooper restricts the solution temperature below the final solidification point in order to avoid the melting of copper-rich phases.

Influence of solution treatment on mechanical properties (strength tensile $-R_{m}$ and Brinell hardness - HBS) for recycled AlSi9Cu3 cast alloy is shown in Figs. 4 and 5. After solution treatment, tensile strength, ductility and hardness are remarkably improved, compared to the corresponding as-cast condition.

By increasing the solution holding time from 2 to $4 \mathrm{~h}$, the tensile strength increased to $273 \mathrm{MPa}$ for $515{ }^{\circ} \mathrm{C}$. With further increase in solution temperature more than $515^{\circ} \mathrm{C}$ and solution time more than 8 hours, tensile strength gently decreases during the whole solution period. This suggests that to enhance the tensile strength of this alloy by increasing the solution temperature more than $515^{\circ} \mathrm{C}$ and by extending the solution time does not seem possible. Peak strength is reached after $4-8 \mathrm{~h}$ of natural ageing.

The results of hardness (Fig. 5) are comparable with results of tensile strength. The highest hardness was $124 \mathrm{HBS}$ for $515^{\circ} \mathrm{C} / 4$ 


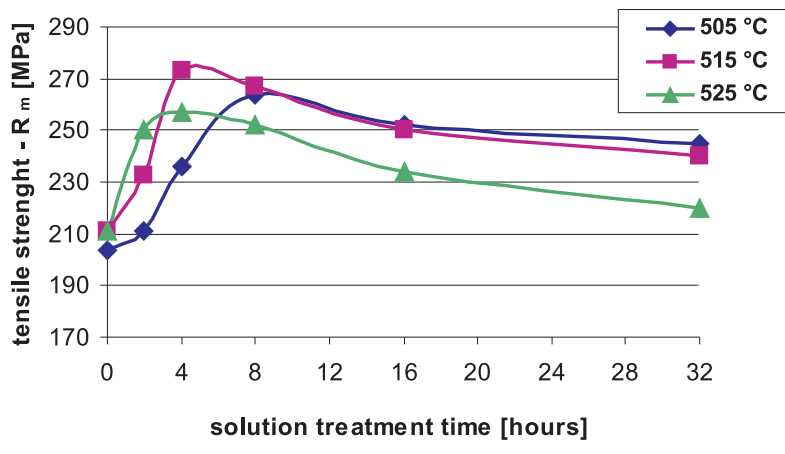

Fig. 4 Influence of solution treatment on strength tensile

hours. At $525^{\circ} \mathrm{C}$, test bars show hardness strong reduction due to the melting of the $\mathrm{Al}_{-} \mathrm{Al}_{2} \mathrm{Cu}-\mathrm{Si}$ phase [14-17].

\subsection{The effect of solution treatment on the Fe-rich phases}

The influence of iron on mechanical properties of aluminium alloys depends on the type, morphology and quantity of iron in the

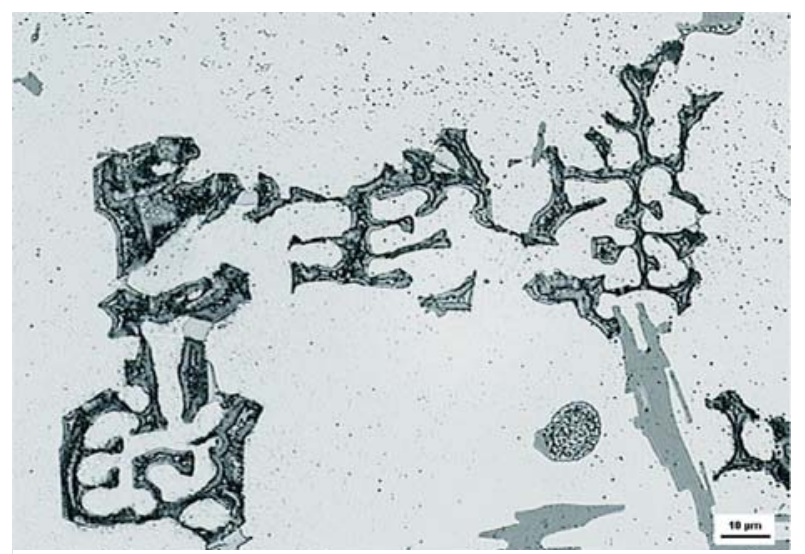

a) untreated state

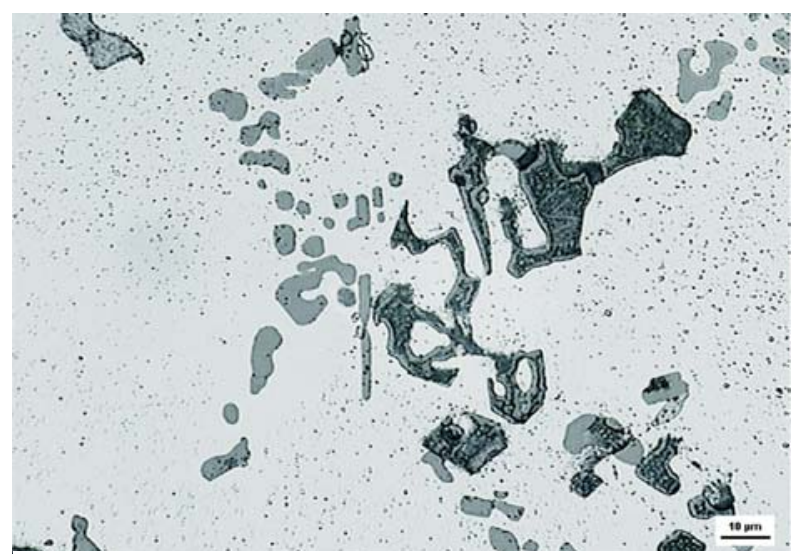

c) $515^{\circ} \mathrm{C}, 4$ hours

Fig. 6 Changes in morphology of $\mathrm{Al}_{15}(\mathrm{FeMn})_{3} \mathrm{Si}_{2}$ phases during solution treatment, etch. $\mathrm{H}_{2} \mathrm{SO}_{4}$

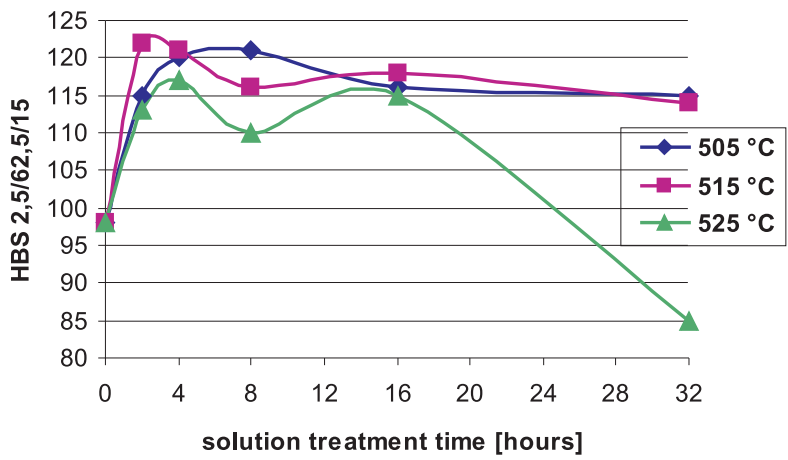

Fig. 5 Influence of solution treatment on hardness

melt. Nevertheless, the shape of iron compounds is more influential than the quantity of those iron compounds.

The evolution of the Fe-rich phases during solution treatment is described in Fig. 6. $\mathrm{Al}_{5} \mathrm{FeSi}$ phase is dissolved into very small needles (difficult to observe). The $\mathrm{Al}_{15}(\mathrm{MnFe})_{3} \mathrm{Si}_{2}$ phase was fragmented to smaller skeleton particles. In the untreated state $\mathrm{Al}_{15}(\mathrm{FeMn})_{3} \mathrm{Si}_{2}$ phase has a compact skeleton-like form (Fig. 6a). Solution treatment of this skeleton-like phase by $505^{\circ} \mathrm{C}$ tends to

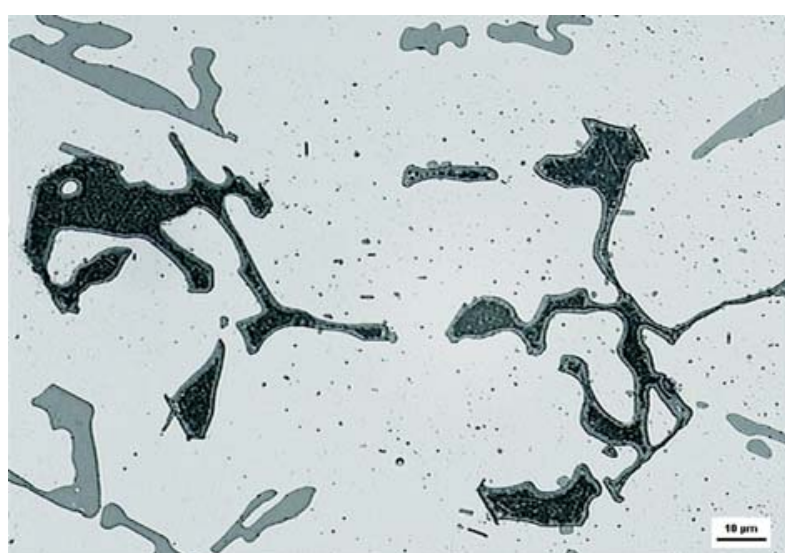

b) $505^{\circ} \mathrm{C}, 4$ hours

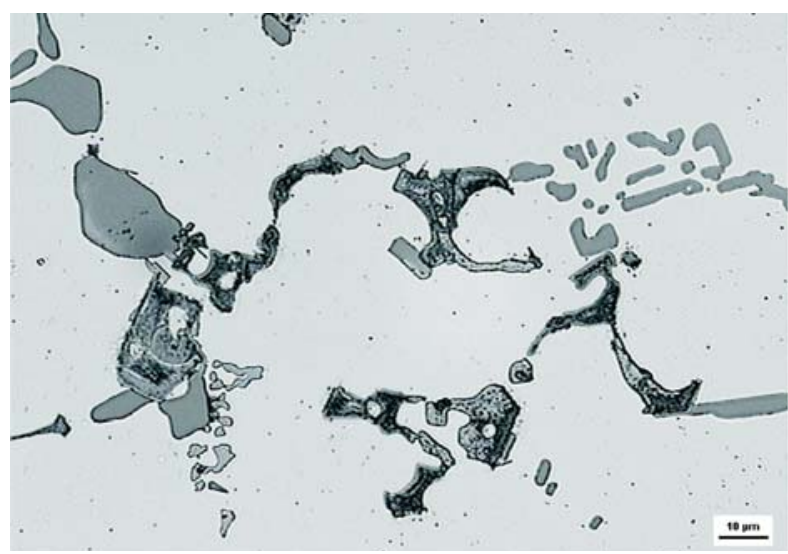

d) $525^{\circ} \mathrm{C}, 4$ hours 
fragmentation (Fig. 6b) and by 515 or $525^{\circ} \mathrm{C}$ to spheroidization and segmentation (Fig. 6c, Fig. 6d).

It was established too that the temperature increase of solution treatment was attended not only by fragmentation of $\mathrm{Al}_{15}(\mathrm{MnFe})_{3} \mathrm{Si}_{2}$ phase, but also by decrease of area share of all Fe-rich phases in AlSi9Cu3 alloy. For the non-heat treated state the area share of Fe-rich phase was c. $4.5 \%$, for temperature $515{ }^{\circ} \mathrm{C} \mathrm{c.} 1.6 \%$ and for $525{ }^{\circ} \mathrm{C}$ only c. $1.3 \%$. Solution treatment reduces its area rather than changes its morphology.

Quantitative metallography [18-19] was carried out on an Image Analyzer NIS - Elements to quantify Fe- rich phases (average area) morphology changes, during solution treatment. Fig. 7 shows the changes in the average area of Fe-rich phases during solution treatment. The maximum average area of Fe-rich phases was observed in as-cast samples $\left(2495 \mu^{2}\right)$. By increasing the solution

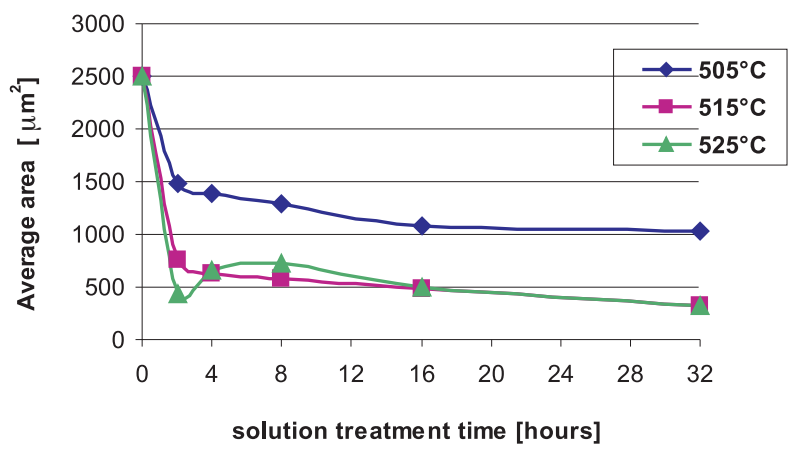

Fig. 7 Changes in average area of Fe-rich phases temperature the average area of Fe-phases dropped to $320 \mu \mathrm{m}^{2}$ for $515{ }^{\circ} \mathrm{C}$. With a prolonged solution treatment time more than $8 \mathrm{~h}$, the extent of dissolution of Fe-rich phases changed little.

\section{Conclusions}

In the present study, the evolution of the Fe-rich phases in recycled AlSi9 $\mathrm{Cu} 3$ cast alloy during solution treatment was investigated. Microstructural characteristic and mechanical properties were studied. From the analysis of the results the following conclusions can be drawn:

- Two Fe-rich phases - $\mathrm{Al}_{5} \mathrm{FeSi}$ needles and skeleton-like $\mathrm{Al}_{15}(\mathrm{FeMn})_{3} \mathrm{Si}_{2}$ were observed. $\mathrm{Al}_{15}(\mathrm{FeMn})_{3} \mathrm{Si}_{2}$ phase was dominant thanks to the presence of $\mathrm{Mn}$.

- The morphology and size of iron phases are highly dependent on the solution treatment. Platelets Fe-rich phases $\left(\mathrm{Al}_{5} \mathrm{FeSi}\right)$ are dissolved into very small needle phases. Skeleton-like Fe-rich phases $\left(\mathrm{Al}_{15}(\mathrm{FeMn})_{3} \mathrm{Si}_{2}\right)$ are fragmented and dissolved (average area reduces from 2495 to $\left.320 \mu \mathrm{m}^{2}\right)$.

- Optimal solution treatment $\left(515^{\circ} \mathrm{C} / 4\right.$ hours $)$ most improves mechanical properties. With further increases of solution treatment time (more than 4 hours) was tensile strength continuously dropped. Brinell hardness by increasis of solution treatment time dropped too. The temperature $525^{\circ} \mathrm{C}$ is not suitable for secondary $\mathrm{AlSi} 9 \mathrm{Cu} 3$ cast alloy solution treatment, because $\mathrm{Cu}$-rich phases $\left(\mathrm{Al}-\mathrm{Al}_{2} \mathrm{Cu}-\mathrm{Si}\right)$ are melt at this temperature [20].

\section{Acknowledgement}

This work has been supported by the Scientific Grant Agency of the Ministry of Education of the Slovak Republic and Slovak Academy of Sciences, $N^{\circ} 1 / 0208 / 08$ and No1/0249/09.

\section{References}

[1] RIOS, C. T. et al.: Intermetallic Compounds in the Al-Si-Cu system, In: Acta Microscopia, 12, 2003, 77-82.

[2] LI, R.: Solution Heat Treatment of 354 and 355 Cast Alloys, In: AFS Transaction, No. 26, 1996, pp. 777-783.

[3] DAS, S. K.: Designing Aluminium Alloys for a Recycling Friendly World, In: Materials Science Forum, Vol. 519-521, 2006, pp. 1239-1244.

[4] TAYLOR, J. A.: The Effect of Iron in Al-Si Casting Alloys, Proc. of $35^{\text {th }}$ Australian Foundry Institute National Conference, Adelaide, South Australia, 2004, pp. 148-157.

[5] PARAY, F., GRUZLESKI, J. E.: Microstructure-mechanical Property Relationships in a 356 alloy - part I., In: Microstructure, Cast Metals, No. 7, 1994, pp. 29-40.

[6] CACERES, C. H., SVENSON, I. L., TAYLOR, J. A.: Strenght-ductility Behaviour of Al-Si-Cu-Mg Casting Alloys in T6 temper, In: Int. J. Cast Metals Res., No. 15, 2003, pp. 531-543.

[7] WANG, Q. G., APELIAN, D., LADOS, D.A.: Fatigue Behavior of A356/357 Aluminum Cast Alloys - part II. Efect of Microstructural Constituents, In: J. of Light Metals 1/2001, pp. 85-97.

[8] TILlOVA, E., CHALUPOVA, M., PANUSKOVA, M.: Structural Analyses of the Al-Si-Cu Alloys, In: Materials Engineering, No. 13, 2006, pp. 25-30.

[9] SEIFEDINE, S., JOHANSSON, S., SVENSSON, I.: The Influence of Cooling Rate and Manganese Content on the $\beta$ - $\mathrm{Al}_{5} \mathrm{FeSi}$ Phase Formation and Mechanical Properties of Al-Si-based Alloys, In: Materials Science and Engineering A, No. 490, 2008, pp. 385-390.

[10] SAMUEL, A. M., SAMUEL, F. H., DOTY, H. W.: Observation on the Formation B-Al ${ }_{5} F e S i$ Phase in 319 type Al-Si Alloys, In: J. of Materials Science, No. 31, 1996, pp. 5529-5539. 
[11] MOUSTAFA, M. A.: Effect of Iron Content on the Formation of B-Al5FeSi and Porosity in Al-Si Eutectic Alloys, In: J. of Materials Processing Technology, No. 209, 2009, pp. 605-610.

[12] SHABESTARI, S. G.: The Effect of Iron and Manganese on the Formation of Intermetallic Compounds in Aluminum-silicon Alloys, In: Materials Science and Engineering A, No. 383, 2004, pp. 289-298.

[13] ASHTARI, P., TEZUKA, H., SATO, T.: Modification of Fe-containing Intermetallic Compounds by K Addition to Fe-rich AA319 Aluminum Alloys, In: Scripta Materialia 53, 2005, pp. 937-942.

[14] SAMUEL, F. H.: Incipient Melting of $\mathrm{Al}_{5} \mathrm{Mg}_{8} \mathrm{Si}_{6} \mathrm{Cu}_{2}$ and $\mathrm{Al}_{2} \mathrm{Cu}$ Intermetallics in Unmodified and Strontium-modified Al-Si-Cu-Mg (319) Alloys During Solution Heat Treatment, In: J. of Materials Science, No. 33, 1998, pp. 2283-2297.

[15] TILLOVA, E., PANUSKOVA, M.: Effect of Solution Treatment on Intermetallic Phase's Morphology in AlSi9Cu3 Cast Alloy,In: Mettalurgija/METABK No. 47, 2008, pp, 133-137, 1-4.

[16] TILLOVA, E., PANUSKOVA, M.: Effect of Solution Treatment on Intermetallic Phase's Morphology in AlSi9Cu3 Cast Alloy, In: Materials Engineering, No. 14, 2007, pp. 73-76.

[17] PANUSKOVA, M., TILlOVA, E., CHALUPOVA, M.: Relation Between Mechanical Properties and Microstructure of Cast Aluminum Alloy AlSi9Cu3, In: Strength of Materials, Vol. 40, 1/2008, pp. 98-101.

[18] SKOCOVSKY, P., VASKO, A.: Quantitative Evaluation of Structure in Cast Iron, EDIS, Zilina, 2007.

[19] VASKO, A., BELAN J.: Comparison of Methods of Quantitative Metallography, In. Improvement of Quality Regarding processes and Materials (ed(s): Borkowski, S. and Tillova, E.), PTM, Warszawa, PL, 2007, pp. 53-58.

[20] HURTALOVA, L., TILlOVA, E.: Evolution of the Structure in Recycled AlSi9Cu3 Cast Alloy During Solution Treatment, In: $J$. of Machine Manufacturing, XLIX, E3-E5, 2009, pp. 6-13. 